\title{
Purification and characterization of thermostable chitinase from a novel S. maltophilia strain
}

\author{
Rifat Hamid", Mahboob Ahmad', Malik M. Ahmad², M. Z. Abdin², Saleem Javed* \\ ${ }^{1}$ Molecular Biology and Biotechnology Laboratory, Department of Biochemistry, Jamia Hamdard, New Delhi-110062 \\ ${ }^{2}$ Centre for Transgenic Plant Development, Department of Biotechnology, Jamia Hamdard, New Delhi-110062 \\ E-mail:saleemjaved70@yahoo.co.in
}

Received 11 May 2012; Received in revised form 16 July 2012; Accepted 18 July 2012

\begin{abstract}
Aims: The presents study examines the purification and characterization of a chitinase from S. maltophilia SJ602 strain isolated from a soil sample collected from Jamia Hamdard, New Delhi.

Methodology and Results: The purification steps included chitin affinity using colloidal chitin as the affinity matrix and column chromatography using Sephadex G-100. The chitinase was purified to 5.85 fold having a yield of $17 \%$. The molecular weight of the chitinase was found to be around $29 \mathrm{kDa}$ by sodium dodecyl sulfate-polyacrylamide gel electrophoresis (SDS-PAGE). The $\mathrm{pH}$ and temperature optima of the purified chitinase were found to be at $\mathrm{pH} 5.5$ and $60^{\circ} \mathrm{C}$, respectively.
\end{abstract}

Conclusion, Significance and Impact of the study: Besides showing a significant yield, the enzyme has a high thermal stability which has its applicability in the recycling of chitin waste.

Keywords: Chitinase, S. maltophilia, chitin affinity, chitinase purification

\section{INTRODUCTION}

The word chitin comes from a Greek word "envelope" and came to light in 1811. It came to be known as a substance that occurs in mushrooms (Ruiz-Herrera, 1978). Chitin, the second most abundant polysaccharide in nature, is a linear $\beta-1,4$ linked polymer of $\mathrm{N}$-acetylglucosamine (Flach et al., 1992). Chitin, a structural component of the fungal cell wall (Blumenthal and Roseman, 1957), is also the major constituent of arthropod exoskeletons, tendons, and the linings of their respiratory, excretory, and digestive systems (Clark and Smith, 1936 and Herring, 1979). It is found in outer skeleton of insects, fungi, yeasts, algae, crabs, shrimps, and lobsters, as well as in the internal structures of a number of invertebrates (Bhattacharya et al., 2007). A report based on lectin binding, endo-chitinase binding and enzymatic degradation suggests that the Paralipophrys trigloides (fish) has chitinous epidermal cuticle (Wagner et al., 1993). In contrast to cellulose, chitin, in addition to a carbon source, can provide nitrogen (6.89\%) as well (C:N = 8:1) (Monreal and Reese, 1969) which makes it a useful chelating agent (Muzzarelli, 1973). Chitin and associated materials have an extensive usage in drug delivery, wound healing, dietary fibre and waste water treatment (Kadowaki et al., 1997, Dixon, 1995, Muzzarelli, 1997, Muzzarelli, 1999, Flach et al., 1992). Chitin is a white, hard, inelastic polysaccharide, and is a major contribution to pollution in coastal areas (Muzzarelli, 1973, and Zikakis, 1984).

Catabolism of chitin includes the initial cleavage of the chitin polymer by chitinases into chitin oligosaccharides and additional cleavage to $\mathrm{N}$ acetylglucosamine, and monosaccharides by chitobiases (Suginta et al., 2000). Chitinases (EC 3.2.1.14, also called chitodextrinase; 1,4-s-poly-N acetylglucosaminidase; polys-glucosaminidase; s-1,4-poly- $\mathrm{N}$-acetyl glucosaminidase) are glycosyl hydrolases which catalyzes the hydrolytic cleavage of the $s-1,4$-linked polymer of $\mathrm{N}$-acetyl- $\beta-\mathrm{D}$ glucosamine (GlcNAc) of chitin. Chitinases are known to be produced by numerous organisms that include bacteria Bacillus, Aeromonas, Alteromonas (Tsujibo et al., 1993), Pseudomonas, Serratia, Vibrio, Streptomyces (Blaak and Schrempf, 1995), and Escherichia (West and Colwell, 1984), fungi (Trichoderma and Aspergillus), invertebrates and vertebrates (Bhattacharya et al., 2007). The size range of chitinases varies from $20 \mathrm{kDa}$ to about $90 \mathrm{kDa}$. Bacterial chitinases have a molecular weight range of $\sim 20-60 \mathrm{kDa}$, which is similar to that of plant chitinases $(\sim 25-40 \mathrm{kDa})$ but are smaller than insect chitinases ( 40$85 \mathrm{kDa}$ ) (Bhattacharya et al., 2007). Chitinases have been divided into two main groups: endo-chitinases (E.C 3.2.1.14) and exo-chitinases (E.C 3.2.1.52). Comparative to exo-chitinases, endochitinases randomly split chitin at internal sites, thereby forming the dimmers of diacetylchitobiose and soluble low molecular mass 
multimers of GlcNAc such as chitotriose, and chitotetraose (Sahai and Manocha, 1993). Chitinases hold a lot of importance due to the fact that they have vast bioprocessing and biotechnological aspects. They find use in things like biological control (Mathivanan et al., 1998), production of ophthalmic products (Dahiya et al., 2006), regeneration of protoplasts (Dahiya et al., 2007), mosquito control (Mendonsa et al., 1996) and production of single cell protein (Vyas and Deshpande, 1991), etc.

The objective of the current study was to isolate and purify the chitinase from a novel $S$. maltophilia strain followed by its characterization on the basis of $\mathrm{pH}$, temperature, molecular weight, and chitinase activity. The purified chitinase was then subjected to different metal ions concentration for analysing their effect on chitinase activity.

\section{MATERIALS AND METHODS}

\section{Bacterial Culture and Growth Conditions}

The bacterial strain used in the present study was Stenotrophomonas maltophilia SJ602 (Accession No. EU492391). It was isolated from the soil and later characterized by $16 \mathrm{~S}$ rRNA sequencing of the amplified product (Khan et al., 2010). The bacterial culture was inoculated in media containing chitin $(4.94 \mathrm{~g} / \mathrm{l})$, maltose $(5.56 \mathrm{~g} / \mathrm{l})$, yeast extract $(0.62 \mathrm{~g} / \mathrm{l}), \mathrm{KH}_{2} \mathrm{PO}_{4}(1.33 \mathrm{~g} / \mathrm{l})$, and $\mathrm{MgSO}_{4} \cdot 7 \mathrm{H}_{2} \mathrm{O}(0.65 \mathrm{~g} / \mathrm{l})$ as described by Khan et al., (2010) and the $\mathrm{pH}$ was adjusted to 7.0. The bacterial culture was incubated at $37^{\circ} \mathrm{C}$ for $72 \mathrm{~h}$ at an rpm of 180 . The obtained culture was centrifuged for $20 \mathrm{~min}$ at 7,000 $\times \mathrm{g}$. The culture supernatant was filtered while the pellet was discarded. The supernatant was stored at $4{ }^{\circ} \mathrm{C}$ for further purification of the chitinase. Chitinase activity was estimated at each purification step.

\section{Preparation of Colloidal Chitin}

Colloidal chitin was prepared as described by Khan et al., (2010). The practical grade chitin powder (HiMedia, India) was used to prepare the colloidal chitin. Chitin powder (40 g) was dissolved in $500 \mathrm{~mL}$ of concentrated hydrochloric acid and continuously stirred at $4{ }^{\circ} \mathrm{C}$ for $1 \mathrm{~h}$. After stirring, the hydrolyzed chitin was washed a number of times with distilled water in order to remove the acid completely and hence bring the $\mathrm{pH}$ in the range of 6-7. As the desired $\mathrm{pH}$ was attained, the colloidal chitin was filtered through Whatman filter paper No.1. The sieved colloidal chitin was subsequently collected and stored in the form of a paste at $4{ }^{\circ} \mathrm{C}$. This colloidal chitin was used at $5 \%$ of the composition of the medium as the sole carbon source with other minimal salts and agar.

\section{Biochemical Quantification of Chitinase}

The chitinase activity in the culture supernatant and at all purification steps was estimated as described by Khan et al. (2010) using colloidal chitin as the substrate (Vyas and Deshpande, 1991). The assay mixture for the chitinase activity contained $1 \mathrm{~mL} 5 \%$ colloidal chitin, $1 \mathrm{~mL} 50 \mathrm{mM}$ acetate buffer, $\mathrm{pH} 5.0$, and $1 \mathrm{~mL}$ enzyme solution, was incubated for $1 \mathrm{~h}$ at $50{ }^{\circ} \mathrm{C}$. The reaction mixture was boiled for $15 \mathrm{~min}$ to stop the reaction followed by centrifugation for $20 \mathrm{~min}$ at $7,000 \times \mathrm{g}$. The chitinase activity was measured spectrophotometrically (Spectronic 20 Genesys) at $540 \mathrm{~nm}$ based on the concentration of released GlcNac (N-acetyl D-glucosamine; the repeating units of chitin) produced with colloidal chitin as substrate (Monreal and Reese, 1969), from the aliquots following a 3, 5-Dinitrosalicylic acid (DNS) sugar estimation test using GlcNac as standard. One unit of chitinase activity was defined as the amount of enzyme, which releases $1 \mathrm{mM}$ $\mathrm{N}$-acetyl-D-glucosamine per minute under the standard conditions of this study.

\section{Purification of Chitinase}

All purification steps of chitinase were performed at $4{ }^{\circ} \mathrm{C}$ unless otherwise mentioned. The first step of the chitinase purification was chitin affinity. An equal volume of culture filtrate and $5 \%$ colloidal chitin was incubated overnight at $4{ }^{\circ} \mathrm{C}$ followed by centrifugation at $10,000 \times \mathrm{g}$ for $25 \mathrm{~min}$, in order to remove the unabsorbed proteins. The supernatant was discarded and pellet was washed 2-3 times with an equal volume of $50 \mathrm{mM}$ sodium acetate buffer ( $\mathrm{pH} 5$ ). The pellet was then dissolved in the same buffer and incubated for $3-5 \mathrm{~h}$ at $37{ }^{\circ} \mathrm{C}$ with continuous shaking for the release of enzyme from chitin. The enzyme/colloidal chitin suspension was then centrifuged at $10,000 \times \mathrm{g}$ for $25 \mathrm{~min}$ to eliminate the colloidal chitin in the form of pellet. The obtained clear supernatant was lyophilized and afterwards applied to a Sephadex G-100 column which was pre-equilibrated with $50 \mathrm{mM}$ Tris $\mathrm{HCl}$ $(\mathrm{pH} 7.5)$ containing $100 \mathrm{mM} \mathrm{NaCl}$ at a flow rate of 0.5 $\mathrm{mL} / \mathrm{min}$. The eluate was subsequently dialyzed overnight. The enzyme solution thus obtained was used for further characterisation of the chitinase.

\section{Determination of Protein Concentration}

In case of the crude samples protein content was determined by the method described by Lowry et al., (1951) with BSA as standard.

\section{Molecular Weight Determination}

The molecular weight of the purified enzyme was determined under both native and denatured conditions by the method described by Laemmli (1970), using 12\% resolving gel and $5 \%$ stacking gel. Silver staining was performed for the visualisation of protein bands. A broad range molecular weight marker (Merck, India) was used having myosin: $205 \mathrm{kDa}$; phosphorylase B: $97.4 \mathrm{kDa}$; bovine serum albumin: $66 \mathrm{kDa}$; egg albumin: $43 \mathrm{kDa}$; carbonic anhydrase: $29 \mathrm{kDa}$; lysozyme: $14.3 \mathrm{kDa}$; aprotinin: $3 \mathrm{kDa}$; insulin $\alpha$ and $\beta$ chains $2.3-3.4 \mathrm{kDa}$.

\section{Characterisation of Purified Chitinase}

The purified enzyme was characterised on the basis of $\mathrm{pH}$ and temperature. The optimum $\mathrm{pH}$ was determined by 
varying the $\mathrm{pH}$ of the assay mixture between 3.0 and 9.5 at an increment of $0.5 \mathrm{pH}$ unit. The temperature optimum of the purified enzyme was also determined with a temperature range of $10-80{ }^{\circ} \mathrm{C}$. The buffer used was 50 $\mathrm{mM}$ sodium acetate.

The effect of different metal ions on the activity of the chitinase was also determined. The chitinase activity was assayed at $50{ }^{\circ} \mathrm{C}$ with an incubation period of $1 \mathrm{~h}$. The metal ions used in the study were $\mathrm{Fe}^{2+}, \mathrm{Mg}^{2+}, \mathrm{Ca}^{2+}, \mathrm{Mn}^{2+}$, $\mathrm{Co}^{2+}$. The metal ions were used in three different concentrations of $2.0,5.0$ and $10 \mathrm{mM}$, respectively. The solution mixture having no metals $(0 \mathrm{mM})$ was treated as control.

\section{RESULTS and DISCUSSION}

The summary of the purification of chitinase from novel $S$. maltophilia strain is given in the Table 1 . The chitinase was purified upto 5.85 fold in a two step procedure with a recovery of $17 \%$. The chitinase was purified to homogeneity which showed a single protein band on $12 \%$ SDS as well as on native PAGE. Its molecular weight was predicted to be approximately $29 \mathrm{kDa}$ by SDS-PAGE (Figure 1). As reported, chitinases have been isolated from Aeromonas (Wu et al, 2001), Bacillus (Bhushan and Hoondal, 1998, Wen et al., 2002), Pseudomonas (Lee et al., 2000), Serratia (Duzhak, 2002) and Streptomyces spp. (Tanabe et al., 2000) having a molecular weight range of 21 to $89.8 \mathrm{kDa}$. Few authors have reported about bacteria producing many types of chitinases differing in size while some produce only single chitinase such as Duzhak et al., (2002) have reported the production of several chitinases with molecular weight of $62,54,43,38$ and $21 \mathrm{kDa}$ by Serratia marcescens, etc. Researchers have also reported the production of several chitinases from Bacillus temperature range of $10-80{ }^{\circ} \mathrm{C}$ in $50 \mathrm{mM}$ sodium acetate buffer ( $\mathrm{pH}$ 5.5) using colloidal chitin as the substrate for 1 h. The chitinase exhibited maximum activity at $60{ }^{\circ} \mathrm{C}$ although it lost half of its activity at $70^{\circ} \mathrm{C}$. There was a substantial decrease in the chitinase activity after $60{ }^{\circ} \mathrm{C}$ and activity was negligible at $80^{\circ} \mathrm{C}$ (Figure 3). The study of $29 \mathrm{kDa}$ chitinase categorized here has optimal activity at $\mathrm{pH} 5.5$ and at $60{ }^{\circ} \mathrm{C}$ was in close agreement with the bacterium thuringiensis subsp. pakistani having molecular weight of $66,60,47$ and $32 \mathrm{kDa}$ in size (Thamthiankul, 2001).

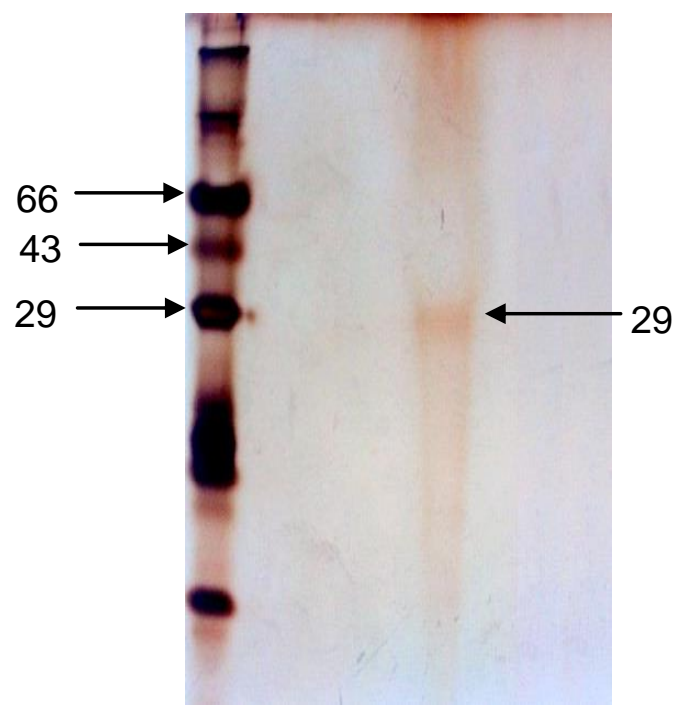

Figure 1: SDS-PAGE of the purified chitinase of bacterium S. maltophilia SJ602

Table 1: Summary of protein purification of $S$. maltophilia chitinase.

\begin{tabular}{|l|c|c|c|c|c|}
\hline Purification steps & $\begin{array}{c}\text { Total Affinity } \\
\text { (Units) }\end{array}$ & $\begin{array}{c}\text { Total Protein } \\
\text { (mg) }\end{array}$ & $\begin{array}{c}\text { Specific Activity } \\
\text { (Units/mg) }\end{array}$ & Fold purification & Recovery (\%) \\
\hline Crude & 21 & 3.0 & 7 & - & 100 \\
\hline Chitin affinity & 50 & 2.5 & 20 & 2.86 & 59 \\
\hline Lyophilized fraction & 120 & 1.5 & 80 & 4.0 & 28 \\
\hline Sephadex G-100 & 375 & 0.8 & 468 & 5.85 & 17.85 \\
\hline
\end{tabular}

The $\mathrm{pH}$ optima studies on the purified chitinase showed that the enzyme was optimally active at $\mathrm{pH} 5.5$. It showed a relatively good stability between $\mathrm{pH} 5-8$ while at $\mathrm{pH} 9.5$, activity of chitinase was almost lost (Figure 2). The $\mathrm{pH}$ optima studies of various other chitinases have shown that the chitinase from $T$. lanuginosus exhibited the highest activity at pH 4.5 (Guo et al., 2008), Aeromonas sp. and Ralstonia sp. at pH 5.0. (Mitsuhiro et al., 2005; Lien et al., 2007), Microbispora sp. at pH 3.0. (Nawani et al., 2002), Bacillus cereus at pH 5.8 (Wang et al., 2001), while Bacillus circulans and Beauveria bassiana showed $\mathrm{pH}$ optima at $\mathrm{pH} 8.0$ and 9.2 (Suresh and Chandrasekaran, 1999) respectively.

In order to determine the optimum temperature of the purified chitinase, the reaction was carried out at the
Microbispora sp. V2 (Nawani et al., 2002) which produces

chitinase at high temperature and acidic $\mathrm{pH}$ for optimal activity. High temperature optima have been reported for chitinases of Bacillus licheniformis (Takayanagi et al., 1991), which produces four exo-chitinases with temperature optima of $70-80{ }^{\circ} \mathrm{C}$ and $\mathrm{pH}$ optima ranging 5.0-6.0. However, Sakai et al., (1998) isolated three thermostable endo-chitinases at temperatures ranging from $65-75^{\circ} \mathrm{C}$ Bacillus sp.

The effects of various metal ions on the chitinase activity are shown in Figure 4 . It was found that the enzyme activity of chitinase was significantly increased with the addition of $\mathrm{Mn}^{2+}$ and $\mathrm{Co}^{2+}$. From the fig., it was evident that chitinase enzyme was almost twice stimulated 


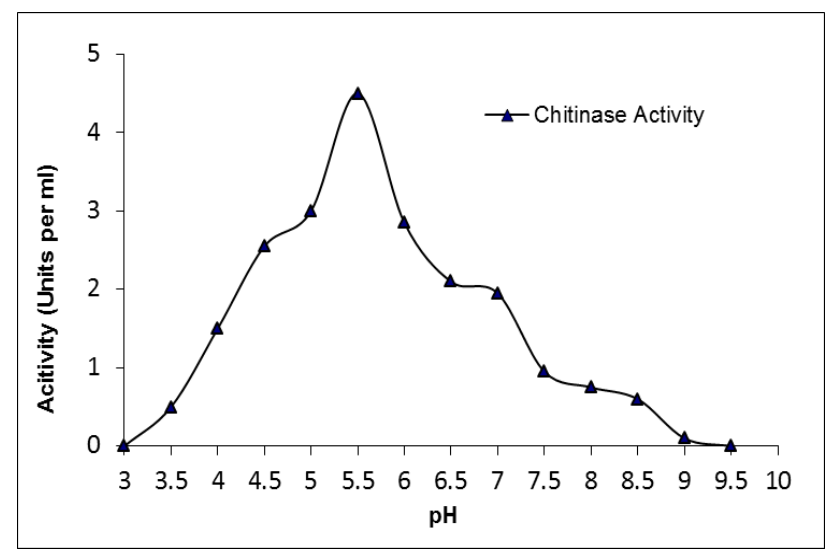

Figure 2: Effect of $\mathrm{pH}$ on activity of chitinase $(-\rightarrow$ from bacterium S. maltophilia SJ602.

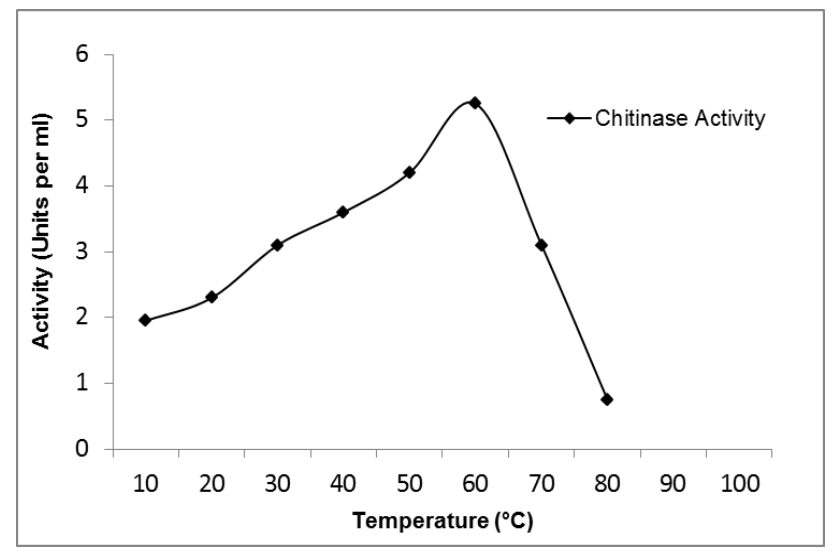

Figure 3: Effect of temperature on activity of chitinase (- $(-)$ from bacterium S. maltophilia SJ602

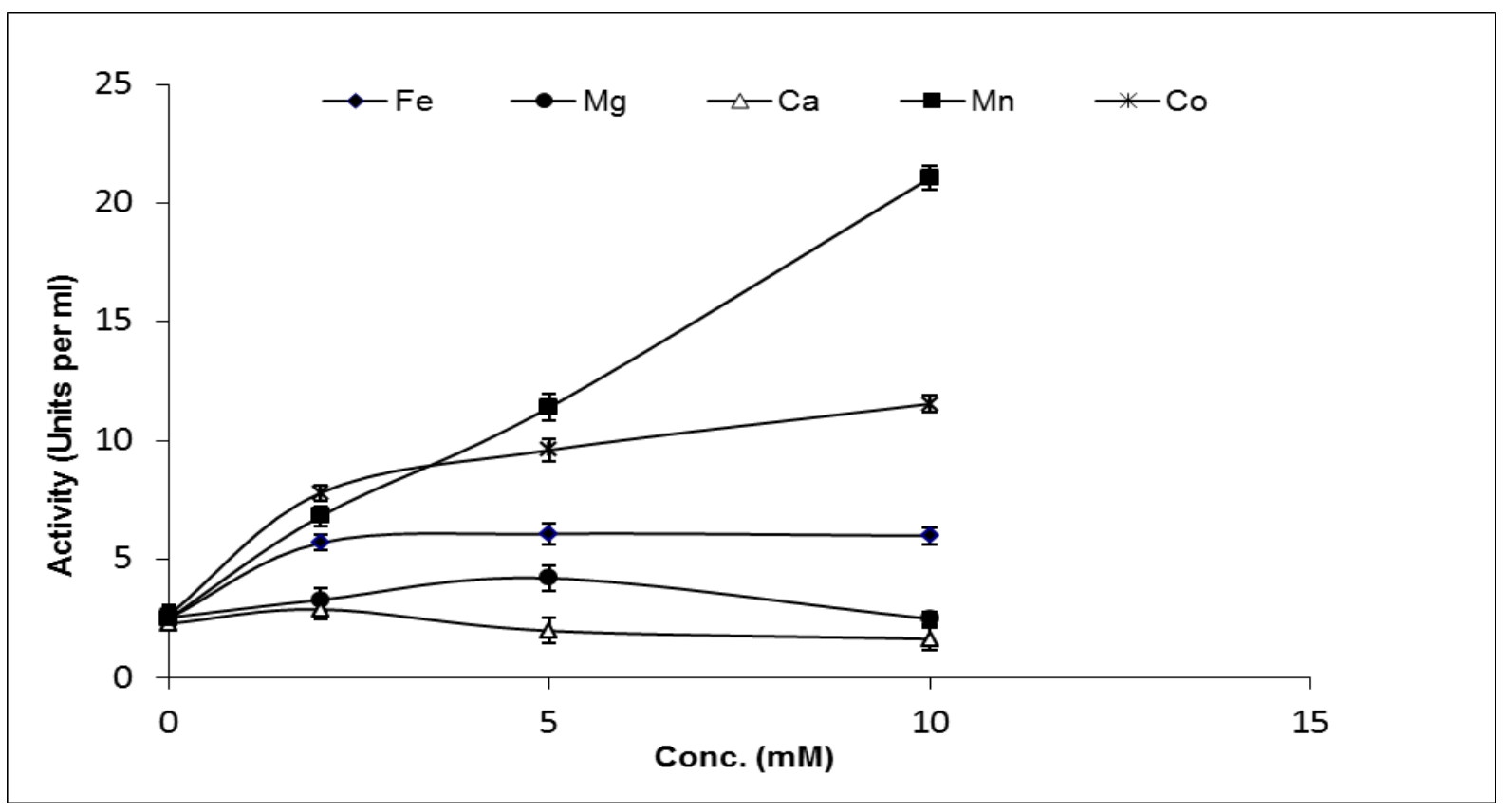

Figure 4: Effect of different metal ions on activity of chitinase from bacterium S. maltophilia SJ602 (a) Fe ( - -), (b) $\mathrm{Mg}(-)$, (c) $\mathrm{Ca}(\boldsymbol{-})$, (d) $\mathrm{Mn}(-),(\mathrm{e}) \mathrm{Co}(\rightarrow)$

by $\mathrm{Mn}^{2+}$ ions than by $\mathrm{Co}^{2+}$ ions. The presence of $\mathrm{Fe}^{2+}$ ions showed slight stimulation in enzyme activity followed by stationary phase even after increasing the metal ion concentration. While, $\mathrm{Mg}^{2+}$ and $\mathrm{Ca}^{2+}$ ions increased the chitinase activity at low concentrations, higher concentrations $(5,10 \mathrm{mM})$ showed decrease in the activity.

The effect of metal ions shows diversity on chitinase activity. Sakai et al., (1998) however, reported that $\mathrm{Fe}^{2+}$ salts have inhibitory effect while $\mathrm{Mg}$ and $\mathrm{Ca}$ have stimulatory affect. This is in contrast to our results which might be due to the bacterial difference and geographical isolation. The chitinase from Bacillus sp. DAU101 (Lee et al., 2000) and Indonesian Bacillus K29-14 (Sri et al., 2004) were increased by $\mathrm{Co}^{2+}$, while the chitinases from bacterium C4 (Yong et al., 2004) and Bacillus $\mathrm{MH}-1$ (Sakai et al., 1998) were activated by $\mathrm{Mn}^{2+}$. It was believed that, the thermostable chitinase from the thermophilic Bacillus sp. Hu1 appeared to be another different type of chitinase, since it was only slightly inhibited by $\mathrm{Cu}^{2+}$ ion and showed increased activity by $\mathrm{Mg}^{2+}, \mathrm{Ca}^{2+}$ and $\mathrm{Zn}^{2+}$. 


\section{CONCLUSION}

In this study, the purification and biochemical characterization of the chitinase produced by novel strain of S. maltophilia in a chitin medium was carried out and the results obtained showed significant yield of the enzyme by the method used. The use of colloidal chitin prepared from practical grade chitin makes it very cost effective for the production of chitinases.

This study also concludes that colloidal chitin can be repeatedly used for at least 10 times with the same sample or the different samples for chitinase production. The high thermal stability of the S. maltophilia SJ602 chitinase is predominantly beneficial for its applicability to

\section{REFERENCES}

Bhattacharya, D. Nagpure, A. and Gupta, R. K. (2007) Bacterial chitinases: properties and potential. Critical Reviews in Biotechnology 27: 21-28.

Bhushan, B. and Hoondal, G. S. (1998). Isolation, purification and properties of a thermostable chitinase from an alkalophilic Bacillus sp. BG-11. Biotechnology Letters 20: 157-159.

Blaak, H. and Schrempf, H. (1995). Binding and substrate specificities of a Streptomyces olivaceovirldis chitinase in comparison with its proteolytically processed form. European Journal of Biochemistry 229: 132-139.

Blumenthal, H. J. and Roseman, S. (1957). Quantitative estimation of chitin in fungi. Journal of Bacteriology 74: 222-224.

Clark, G. L. and Smith, A. F. (1936). X-Ray diffraction studies of chitin, chitosan, and derevatives. The Journal of Physical Chemistry 40: 863-879.

Dahiya, N. Tewari, R. and Hoondal, G. H. (2006). Biotechnological aspects of chitinolytic enzymes: a review. Applied Microbiology and Biotechnology 71: 773-782.

Dahiya, N., Tewari, R., Tiwari, P. Hoondal, G. S. (2005). Production of an antifungal chitinase from Enterobacter sp. NRG4 and its application in protoplast production. World Journal of Microbiology and Biotechnology 21: 1611-1616.

Dixon, B. (1995). Using fungal dressings to heal wounds. Biotechnology 13: 120-121.

Duzhak, A. B., Panfilova, Z. I. and Vasiunina, E. A. (2002). Extracellular chitinase production by wild type B-10 and mutant M-1 strains of Serratia marcescens. Prikladnaia Mikrobiologiia 38: 248-256.

Flach, J. Pilet, P. E. and Jolles, P. (1992). What's new in chitinase research? Experientia 48: 701-716.

Guo, R. F. Shi, B. S. Li, D. C. Ma, W. and Wei, Q. (2008). Purification and characterization of a novel thermostable chitinase from Thermomyces lanuginosus SY2 and cloning of its encoding gene. Agricultural Sciences in China 7: 1458-1465. the recycling of chitin wastes. Generally, during bioconversion of wastes temperature raises, and as the chitinase reported here have high thermal stability; it could be very useful at this stage of recycling. Conclusively, Stenotrophomonas sp. could be used as a suitable model

\section{ACKNOWLEDGEMENT}

S.J. is thankful for financial assistance to the Department of Science and Technology (DST), India. R.H. is thankful to the University Grants Commission (UGC), Govt. of India for providing fellowship.

Herring, P. J. (1979). Marine Ecology and natural products. Pure and Applied Chemistry 51: 19011911.

Kadowaki, S. Saskiawan, I. Watanabe. J. Yamamoto, K. Bunno, M. Ichihara, Y. and Kumagai, H. (1997). Transglycosylation activity of $\beta-N$ acetylhexosaminidase from Penicillium oxalicum and its application to synthesis of a drug carrier. Journal of Fermentation and Bioengineering 83: 341-345.

Khan, M. A. Hamid, R. Ahmad, M. Abdin, M. Z. and Javed, S. (2010). Optimization of culture media for enhanced chitinase production from a novel strain of Stenotrophomonas maltophilia using response surface methodology. Journal of Microbiology and Biotechnology 20: 1597-1602.

Laemmli, U. K. (1970). Cleavage of structural proteins during the assembly of the head of bacteriophage T4. Nature 277: 680- 685.

Lee, Y. Park, I. Yoo, J. Chung, S. Lee, Y. Cho, Y. Ahn, S., Kim, C. and Choi, Y. (2007). Cloning, purification and characterization of chitinase from Bacillus sp. DAU101 Bioresource Technology 98: $2734-2741$.

Lee, H. S. Han, D. S. Choi, S. J. Choi, S. W. Kim, D. S. Bai, D. H., and Yu, J. H. (2000). Purification, characterization and primary structure of a chitinase from Pseudomonas sp. YHS-A2. Applied Microbiology and Biotechnology 54: 397-405.

Lien, T.S. Yu, S. T. Wu, S. T. and Too, J. R. (2007). Induction and purification of a thermophilic chitinase produced by Aeromonas sp. DYU-Too7 using glucosamine. Biotechnology and Bioprocess Engineering 12: 610-617.

Lowry, O.H. Rosebrough, N. J. Farr, A. L. and Randall, R. J. (1951). Protein measurement with the Folin phenol reagent. The Journal of Biological Chemistry 193: 265-275.

Mathivanan, N. Kabilan, V. and Murugesan, K. (1998). Purification, characterization and antifungal activity of chitinase from Fusarium chlamydosporum, a mycoparasite to groundnut rust, Puccinia arachidis. Canadian Journal of Microbiology 44: 646-51.

Mendonsa, E. S. Vartak, P. H., Rao, J. U., and Deshpande, M. V. (1996). An enzyme from 
Myrothecium verrucaria that degrades insect cuticles for biocontrol of Aedes aegypti mosquito. Biotechnology Letters 18: 373-376.

Mitsuhiro, U. Yukiko, K. Aji, S. Masami, N. and Kazutaka, M. (2005). Purification and Characterization of chitinase $B$ from moderately thermophilic bacterium Ralstonia sp. A-471. Bioscience Biotechnology and Biochemistry 69: 842-844.

Monreal, J. and Reese, E. T. (1969). The chitinase of Serratia marcescens. Canadian Journal of Microbiology 15: 689-696.

Muzzarelli, R. A. A. (1973). Natural chelating polymers. Pergamon Press. Oxford, New York, USA. pp. 83.

Muzzarelli, R. A. A. (1997). Human enzymatic activities related to the therapeutical administration of chitin derivatives. Cellular and Molecular Life Sciences 53: 131-140.

Muzzarelli, R. A. A. (1999). Clinical and biochemical evaluation of chitosan for hypercholesterolemia and overweight control. EXS. 87: 293-304.

Nawani, N. N. Kapadnis, B. P. Das, A. D. Rao, A. S. and Mahajan, S. K. (2002). Purification and characterization of a thermophilic and acidophilic chitinase from Microbispora sp. V2. Journal of Applied Microbiology 93: 965-975.

Ruiz-Herrera, J. (1978). The distribution and quantitative importance of chitin in fungi, In Muzzarelli, R. A. A and J. Priser (eds.). Chitin and Chitosan, Proc. First Internal. Conf. MIT, USA. pp. 11-21.

Sahai, A. S, and Manocha, M. S. (1993). Chitinases of fungi and plants: their involvement in morphogenesis and host-parasite interaction. FEMS Microbiology Review 11: 317-338.

Sakai, K. Yokota, A. Kurokawa, H. Wakayama, M. and Moriguchi, M. (1998). Purification and characterization of three thermostable endochitinases of Bacillus noble strain $\mathrm{MH}-1$ isolated from chitin containing compost. Applied and Environmental Microbiology 64: 3340-3397.

Sri, R., Tanuwidjaja, F. Rukayadi, Y. Suwanto, A., Thenawidjaja, S. M. Jae, K. H. and Yu, R. P. (2004). Study of thermostable chitinase enzymes from Indonesian Bacillus K29-14. Journal of Microbiology and Biotechnology 14: 647-652.

Struszczyk, M. H. (2006). Global requirements for medical applications of chitin and its derivatives. In Monograph XI. Polish Chitin Society, Łódź, Poland. pp. 95-102.

Suginta, W. Robertson, P. A. Austin, B. S. Fry, C. and Fothergill-Gillmore, L. A. (2000). Chitinases from vibrio: activity screening and purification of chiA from V. carchariae. Journal of Applied Microbiology 89: 76-84.

Suresh, P. V. and Chandrasekaran, M. (1999). Impact of process parameters on chitinase production by an alkalophilic marine Beauveria bassiana in solid state fermentation. Process Biochemistry 34: 257267.
Takayanagi, T. Ajisaka, K. Takiguchi, Y. and Shimahara, K. (1991). Isolation and characterization of thermostable chitinases from Bacillus licheniformis X-7u. Biochimica et Biophysica Acta 1078: 404-410.

Tanabe, T. Kawase, T. Watanabe, T. Uchida, Y. and Mitsutomi, M. (2000). Purification and characterization of a $49-\mathrm{kDa}$ chitinase from Streptomyces griseus HUT 6037. Journal of Bioscience and Bioengineering 89: 27-32.

Thamthiankul, S. Suan-Ngay, S., Tantimavanich, S. and Panbangred, W. (2001). Chitinase from Bacillus thuringiensis subsp. pakistani. Applied Microbiol and Biotechnology 56: 395-401.

Tsujibo, I. I. Orikoshi, I. I. Tanno, H., Fujimoto, K. Miyamoto, I. L., Imada, C. Okami, Y. and Y, Inamod. (1993). Cloning, sequence and expression of a chitinase gene from a marine bacterium, Alteromonas sp. strain 0-7. Journal of Bacteriology 175: 176-181.

Vyas, P. R. and Deshpande, M. V. (1991). Enzymatic hydrolysis of chitin by Myrothecium verrucaria chitinase complex and its utilization to produce SCP. Journal of General and Applied Microbiology 37: 267-75.

Wagner, G. P., Lo, J. Laine, R., and Almeder, M. (1993). Chitin in the epidermal cuticle of a vertebrate (Paralipophrys trigloides, Blenniidae, Teleostei). Cellular and Molecular Life Sciences 49: 317-319.

Wang, S. Y. Moyne, A. L. Thottappilly, G. Wu, S. J. Locy, R. D. and Singh, N. K. (2001). Purification and characterization of a Bacillus cereus exochitinase. Enzyme and Microbial Technology 28: 492-498.

Wen, C. M. Tseng, C. S. Cheng, C. Y. and Li, Y. K. (2002). Purification, characterization and cloning of a chitinase from Bacillus sp. NCTU2. Biotechnology and Applied Biochemistry 35: 213219.

West, P. A. and Colwell, R. R. (1984). Identification and classification of Vibrionaceae: an overview, In Colweii R. R., (eds.), Vibrios in the environment, John Wiley and Sons, New York, USA. pp. 285363.

Wu, M. L., Chuang, Y. C., Chen, J. P., Chen, C. S. and M. C. Chang. (2001). Identification and characterization of the three chitin-binding domains within the multidomain chitinase Chi92 from Aeromonas hydrophila JP101. Applied and Environmental Microbiology 67: 5100-5106.

Yong, T. Zhangfu, L. Ling, X. Hong, J. Hong, R. Y. Ke, T. Shaorong, G. Ge, L. K. and L, Shigui. (2004). Identification of a chitinase producing bacterium C4 and histopathologic study on locusts pest management. Science 61: 159-165.

Zikakis, J. P. (1984). Chitin, chitosan, and related enzymes. Academic Press, Inc., New York. pp. 213. 